\title{
WACANA POLITIK PENDIDIKAN DALAM PERKEMBANGAN DEMOKRASI DI INDONESIA
}

\author{
Oleh: \\ Husniah Ramadhani Pulungan \\ Dosen Universitas Muhammadiyah Tapanuli Selatan
}

\begin{abstract}
The political education discourse in the development of democracy in Indonesia has influenced the progress of the education system. This is inseparable from the long process of history with various educational political products that have been produced that contribute to the progress of the nation's education. The political education discourse in Indonesia is still proceeding in producing an ideal democratic system. In political discourse, education is still used as one of the main issues in raising public confidence in the leaders, starting from colonialism, a new era, reformation to the present. Thus, the politics of education is one important thing in realizing a positive symbol of democracy in Indonesia.
\end{abstract}

Keyword: discourse; politic; education; democracy

\section{PENDAHULUAN}

Wacana politik pendidikan dalam perkembangan demokrasi di Indonesia telah mempengaruhi kemajuan sistem pendidikannya. Hal ini telah berproses dari setiap periode pemerintahan di Indonesia yang terus berusaha berbenah diri untuk menjadi lebih baik. Namun, tidak dapat dipungkiri bahwa kebijakan politik pendidikan tersebut bergantung pada kebijakan pemerintah yang sedang menjalankan pemerintahannya. Tidak heran, jika ditemukan kebijakan politik pendidikan yang berbeda-beda berdasarkan sudut pandang yang berbeda beserta capaian yang berbeda dari setiap kebijakan yang telah dihasilkan.

Guna memaparkan wacana politik pendidikan dalam perkembangan demokrasi di Indonesia, maka secara umum dalam artikel ini akan disajikan konseptual dari politik pendidikan, wacana politik pendidikan dalam perkembangan demokrasi di Indonesia, dan wacana perkembangan demokrasi di Indonesia terhadap penempatan pendidikan.

\section{PEMBAHASAN}

\section{A. Politik Pendidikan}

Kata politik berasal dari bahasa Inggris politics yang berarti permainan politik ${ }^{1}$. Pada bahasa Indonesia, politik bermakna pengetahuan tentang ketatanegaran atau kenegaraan seperti tata cara pemerintahan, dasar-dasar pemerintahan, dan lain-lain.

\footnotetext{
${ }^{1}$ John M.Echols Shadily, Kamus Inggris Indonesia, Cet.VIII, Jakarta: Gramedia, 1990), h. 437.
} 
Sementara itu, pada bahasa Arab, kata politik dikenal dengan al-siyasah yang berarti reka cipta; upaya-upaya strategis dan pengertahuan tentang sesuatu.

Kemudian, kata pendidikan berasal dari kata didik yang mendapat awalan pendan akhiran -an yang berarti perbuatan; hal; dan cara. Menurut Ki Hajar Dewantara, pendidikan merupakan tuntutan bagi pertumbuhan anak. Hal ini berarti bahwa pendidikan menuntut segala kekuatan kodrat yang ada pada diri anak, agar mereka sebagai manusia sekaligus sebagai anggota masyarakat dapat mencapai keselamatan dan kebahagiaan setinggi-tingginya.

Menurut sejarah, politik pada awalnya berasal dari kata Yunani politen dan diperkenalkan pertama kali oleh Plato (347 SM) dengan makna hal-ihwal mengenai negara dan dikembangkan oleh muridnya Aristoteles (322 SM) yang memahami politik sebagai seni mengatur dan mengurus negara. Politik merupakan suatu proses pembentukan dan pembagian kekuasaan dalam masyarakat yang antara lain berwujud proses pembuatan keputusan, khususnya dalam negara. Pengertian ini merupakan upaya penggabungan antara berbagai definisi yang berbeda mengenai hakikat politik yang dikenal dalam ilmu politik. Politik adalah seni dan ilmu untuk meraih kekuasaan secara konstitusional maupun non-konstitusional.

Di samping itu, politik juga dapat ditilik dari sudut pandang berbeda, antara lain:

1. Politik adalah usaha yang ditempuh warga negara untuk mewujudkan kebaikan bersama (teori klasik Aristoteles).

2. Politik adalah hal yang berkaitan dengan penyelenggaraan pemerintahan dan negara.

3. Politik merupakan kegiatan yang diarahkan untuk mendapatkan dan mempertahankan kekuasaan di masyarakat.

4. Politik adalah segala sesuatu tentang proses perumusan dan pelaksanaan kebijakan publik.

Pada konteks memahami politik perlu dipahami beberapa kunci, antara lain: kekuasaan politik, legitimasi, sistem politik, perilaku politik, partisipasi politik, proses politik, dan juga tidak kalah pentingnya untuk mengetahui seluk beluk tentang partai politik.

Pernyataan di atas merupakan makna pertama tentang politik. Selanjutnya pengertian politik dipahami sebagai kegiatan suatu sistem politik atau negara untuk mencapai tujuan bersama. Pemahaman ini menjadi pemahaman yang paling universal, termasuk di antaranya untuk memahamai kebijakan kebijakan tertentu sebagai upaya merealisasikan tujuan tersebut. Salah satu bentuk derivatnya adalah munculnya istilah politik pembangunan, politik pendidikan, dan seterusnya. ${ }^{2}$

Sedangkan politik pendidikan menurut Dale adalah relasi antara produksi tujuantujuan dan bentuk-bentuk pencapainya. Fokusnya ada pada kekuatan yang menggerakkan machinary, bagaimana dan di mana machinary tersebut diarahkan. Konsentrasi kajian politik pendidikan bagi Dale ada pada peranan negara. Ia yakin

2BN. Marbun, Kamus Politik(t.k: t.p, 2002), h. 445.

Wacana Politik. Husniah 
dengan melalui studi tentang politik pendidikan dapat menerangkan pola-pola, kebijakan, dan proses pendidikan dalam masyarakat secara memadai, di samping memungkinkan kita untuk mempertanyakan persoalan-persoalan di seputar asumsi, maksud dan outcome berbagai strategi perubahan pendidikan. ${ }^{3}$

Istilah politik pendidikan merupakan proses pembuatan keputusan-keputusan penting dan mendasar dalam bidang pendidikan baik di tingkat lokal maupun nasional. ${ }^{4}$

Definisi ini dikemukakan Kimbroug dengan meminjam pengertian politik yang disampaikan Kammerer sebagai proses pembuatan keputusan-keputusan penting yang melibatkan masyarakat luas. Kimbroug lalu menyatakan bahwa pendidikan publik bersifat politis. Mereka yang terlibat dalam manajemen pendidikan publik adalah para politisi, manakala mereka menuntut keputusan, harus melalui proses politik. Berdasarkan pernyataan Kimbrough ini dapat dinyatakan bahwa proyek-proyek penting dalam bidang pendidikan terkait dengan konsep ekonomi, sistem sosial, keuangan, fungsi pemerintah, dan bisinis yang kesemuanya melahirkan aktivitas politik dan bersifat partisan. Oleh sebab itu, para pimpinan lembaga pendidikan akan berhasil jika memahami elemen-elemen penting dari struktur kekuasaan dan menggunakan pengetahuan ini dalam melaksanakan politik sekolah. Kekurangpahaman atas proses politik akan dapat membuat pimpinan lembaga pendidikan mengalami disinformasi sejauhmana prosedur demokratis terlibat dalam pembuatan keputusan. Para administrator pendidikan saatnya memperhatikan tokoh-tokoh lain dalam sistem pengambilan keputusan. Pada konteks berpikir seperti inilah wawasan tentang politik pendidikan berperan penting bagi siapapun yang fokus dengan persoalan pendidikan. Dengan demikian, politik pendidikan adalah segala keijakan pemerintah suatu negara dalam bidang pendidikan yang berupa peraturan perundang-undangan atau lainnya untuk menyelenggarakan pendidikan demi tercapainya tujuan negara.

Berdasarkan pemikiran yang telah disampaikan di atas, maka dapat dinyatakan bahwa politik pendidikan dapat dimaknai sebagai penggunaan kekuasaan untuk mendesakkan kebijakan pendidikan. Sifatnya bisa keras dan bisa lunak. Politik pendidikan dikategorikan keras apabila melibatkan kekuatan (fisik) untuk mendesakkan implementasi kebijakan tertentu. Sebaliknya, politik pendidikan lunak menekankan implementasi kekuasaan secara halus (subtle) lewat strategi taktis. Aksi pemogokan guru, unjuk rasa para guru, merupakan wujud politik pendidikan yang keras. Dalam aksi itu, para pendidik mengolah potensi kekuasaan kolektif mogok untuk menghasilkan kekuatan nyata guna mempengaruhi tatanan keseharian masyarakat (menghentikan kegiatan belajar-mengajar).

Strategi politik seperti itu digunakan untuk melawan politik lunak pemerintah terkait anggaran pendidikan dan tunjangan kesejahteraan guru, dan sebagainya. Sementara upaya yang dilakukan oleh kalangan Ikatan Sarjana Pendidikan Indonesia

\footnotetext{
${ }^{3}$ Dale Roger, The State and Education Policy, Milton Keynes, (UK: Open University Press, 1989), h. 24.

${ }^{4}$ Kimbrough, Political Powerand Educational Decision-Making (Chicago: Rand Mcnally \& Company, 1964), h. 274.
} 
dengan jalan memberi masukan kepada pemerintah tentang kebijakan pendidikan merupakan bagian dari strategi politik lunak. Pencantuman pasal tentang besaran anggaran pendidikan yang harus dilaksanakan pemerintah dan pemerintah daerah dalam UUD 1945 merupakan keberhasilan dalam menjalankan strategi lunak para pendidik.

Berbicara mengenai politik pendidikan, tentunya membicarakan dua hal yang tidak dapat dipisahkan antara politik dan pendidikan. Kedua hal tersebut sesungguhnya sesuai dengan apa yang disampaikan Sirozi sebagai guru besar politik di Indonesia bahwa antara politik dengan pendidikan adalah ibarat antara air dengan gula yang sudah diaduk dalam suatu gelas, maka tidak akan dapat dipisahkan antara gula dengan air yang sudah diaduk tersebut. Oleh karena itu, jika berbicara mengenai politik tentunya pasti disandingkan pembahasan pendidikan.

Akhir-akhir ini, wacana yang didengar di media televisi tidak ubahnya sama dengan wacana pada masa yang lalu, yakni masing masing calon Presiden Republik Indonesia yang mendaftarkan diri sebagai calon presiden dan wakil presiden telah memposisikan pendidikan sebagai salah satu kunci utama dalam merekrut suara di tengah-tengah masyarakat Indonesia. Hal ini terbukti dengan jelas apa yang menjadi prioritas masing-masing calon presiden dan wakil presiden yang telah disampaikan dalam debat presiden dan wakil presiden. Masing-masing telah memiliki komitmen untuk memperbaiki pendidikan di Indonesia. Karena pendidikan dianggap sebagai satu hal yang harus atau mutlak menjadi terobosan baru bagi setiap calon pemimpin. Oleh sebab itu, dengan berbagai cara telah mulai dilakukan untuk memberikan kepastian terkait dengan perekrutan suara demi menumbuhkan kepercayaan masyarakat dalam memilih salah satu calon pemimpin.

Belakangan ini juga dapat disaksikan melalui media televisi terkait dengan kemeriahan pemilihan presiden untuk periode 2019-2024. Masing-masing capres memberikan janji politik khususnya dalam kebijakan pendidikan di Indonesia. Salah satunya, misalnya, jika paslon 02 menang maka istilah Ujian Nasional Berbasis Komputer akan dihapus dengan membuat suatu kebijakan yang baru yakni bagi siswa kelas XII akan diarahkan kepada bakat setiap siswa yang akan tamat dari lembaga pendidikan formal. Hal ini akan membuat kebijakan paslon tersebut dapat memberikan kebijakan baru khususnya dalam bidang evaluasi pendidikan.

Berbeda halnya dengan paslon nomor urut 01 yang akan memberikan biaya pendidikan melalui kartu yang dipergunakan untuk biaya pendidikan. Bahkan setiap tingkatan pendidikan mulai dari Sekolah Dasar (SD) sampai dengan Perguruan Tinggi (PT) akan diberikan biaya pendidikan yang memadai. Demikian pula halnya pada masa Bapak Susilo Bambang Yudhoyono yang juga tidak terlepas dari adanya kebijakankebijakan pendidikan secara politik yang dapat memberikan pengaruh positif pada kepemimpinannya sehingga dapat terus terpilih sebagai pemimpin di Indonesia.

Berdasarkan uraian di atas, maka dapat dipahami bahwa dengan menggabungkan kebijakan politik dengan kebijakan pendidikan memunculkan demokrasi positif dalam pesta demokrasi di Indonesia. Politik pendidikan memiliki hubungan yang erat dan dinamis pada suatu negara. Dengan demikian, maka dapat 
dinyatakan bahwa hubungan politik dan pendidikan adalah realitas empiris yang telah terjadi sejak awal perkembangan peradaban manusia dan terus menjadi perhatian para ilmuwan.

\section{B. Wacana Politik Pendidikan di Indonesia}

Berbicara mengenai wacana politik pendidikan di Indonesia tentunya berawal dari bagaimana perkembangan politik pendidikan pada masa-masa yang lalu. Politik pendidikan juga sangat erat kaitannya dengan situasional atau keadaan yang dialaminya, sehingga lebih mudah untuk memberikan gambaran terkait dengan paradigma politik pendidikan yang ada di Indonesia.

Sebelum kemerdekaan bangsa Indonesia, politik pendidikan menghadapi tantangan yang luar biasa. Tantangan tersebut dapat dilihat dengan munculnya peristiwa penting bagi bangsa Indonesia. Mulai dari penjajahan Belanda selama tiga setengah abad sebelum Indonesia merdeka yakni sebelum tahun 1945. Peristiwa ini menimbulkan terjadinya tiga hal yang perlu disoroti menurut Muhammad Sirozi. Adapaun ketiga hal tersebut dapat dipahami dari pentingnya analisis kebijakan seperti kebijakan itu sendiri dan dampaknya bagi budaya bangsa Indonesia, pendidikan itu sendiri, serta mengenai mentalista bangsa Indonesia. ${ }^{5}$

Kebijakan pendidikan yang dimaksud di atas adalah kebijakan pendidikan yang dikeluarkan atau disusun oleh pihak Belanda, sehingga sangat mempengaruhi budaya bangsa Indonesia hingga kini. Karakteristik kebijakan politik pendidikan Belanda sesungguhnya dapat dilihat dari ciri-cirinya. Menurut Muhammad Sirozi dalam Nasution mengidentifikasi ciri-ciri pendidikan pada masa itu adalah:

1. Pendidikan yang diberikan sangat bertahap bagi anak-anak bangsa Indonesia.

2. Tekanan pada dualisme yang bertentangan antara pendidikan bagi orang Belanda dengan bangsa Indonesia.

3. Pengawasan sentral yang ketat.

4. Sasaran Pendidikan bagi golongan pribumi terbatas, dan penggunaan sekolah menghasilkan buruh kelas rendah.

5. Azas korkondas yang membuat sekolah di Indonesia sama dengan yang ada di Belanda.

6. Tidak ada rencana pendidikan yang sistematik bagi pribumi bangsa Indonesia. ${ }^{6}$

Berdasarkan ciri-ciri yang telah tampak di atas bahwa Belanda sangat menyukai point 1 sampai dengan point 6 tersebut yang telah menjadi peninggalan dalam budaya pendidikan pada bangsa Indonesia. Kemudian, penerapan pendidikan Belanda tersebut hanya dapat dilihat secara simbolik saja. Hal ini berarti bahwa yang dilakukan oleh pihak Belanda sebenarnya belum sesuai dengan keinginan rakyat Indonesia. Namun,

\footnotetext{
${ }^{5}$ Muhammad Sirozi, Politik Kebijakan Pendidikan di Indonesia Peran Tokoh-tokoh Islam dalam Penyususnan UU No.2 Tahun 1989 (Jakarta: INIS, 2004), h. 16.

${ }^{6}$ Sirozi, Politik....., h. 18.
} 
dari pola pendidikan yang telah dilakukan oleh Belanda inilah satu satunya jalan yang menjadi pilihan yang harus diikuti pada saat itu. Hal ini menunjukkan bahwa kebijakan politik pendidikan pada saat ini sebenarnya masih membutuhkan akses yang merata dalam berbagai sektor.

Analisis politik pendidikan seperti ini menurut penulis adalah suatu politik pendidikan yang belum menempatkan politik pendidikan tersebut sesuai dengan apa yang menjadi cita-cita politik pendidikan itu sendiri. Pada gilirannya, kebutuhan dalam memperoleh ilmu pengetahuan tersebut masih perlu untuk ditingkatkan sesuai dengan keinginan masyarakat Indonesia. Peningkatan pengelolaan pendidikan ini dapat ditingkatkan lagi melalui kebijakan politik pendidikan yang dihasilkan sehingga masyarakat dapat merasakan implementasinya secara kontinuitas.

Selanjutnya, terkait dengan kebijakan politik pendidikan Belanda sebelum merdeka, terdapat lembaga pendidikan yang ada di tanah air yang diberikan gerakan terbatas. Lembaga pendidikan seperti Sekolah Alquran yang bermanfaat bagi umat Islam, sekolah tradisional pesantren yang memberikan pendidikan agama lanjut, dan tarekat yang memberikan pelatihan dalam hukum dan doktrin Islam. Hal ini terlihat dari sekolah-sekolah tersebut menjalankan sekolahnya secara mandiri dengan biaya sendiri. Kemudian, pada tahun 1895 kebijakan politik pendidikan telah memasukkan sekolahsekolah tersebut dalam penganggaran dana.

Berikutnya, wacana politik pendidikan pada masa orde baru tahun 1965-1998 dilanjutkan dengan pemberian masukan terkait dengan sistem pendidikan yang harus dilaksanakan oleh bangsa Indonesia telah dilakukan oleh rakyat Indonesia, khususnya para ulama.

Dewasa ini, peran politik para ulama dalam menggagas Undang-Undang Sistem Pendidikan Nasional paling tidak terdapat tiga hal yang perlu diperhatikan. (1) Mereka memfasilitasi pemeliharaan sistem dan penyesuaian fungsi masyarakat, (2) menghubungkan perilaku sistem politik secara keseluruhan dengan sistem sosial lain dan dengan lingkungan, dan (3) memfasilitasi proses peralihan yang mengalihkan tuntutan dan dukungan menjadi luaran kebijakan yang berkewenangan. ${ }^{7}$

Selanjutnya, pada masa orde baru, hal ini sebenarnya sudah dapat dinyatakan dengan sungguh-sungguh. Hal ini karena sistem politik pendidikan telah menaruh azas dari rakyat Indonesia itu sendiri. Selanjutnya, pancasila pun sudah dianggap telah memberikan amanah bagi kedudukan sistem pendidikan yang ada di Indonesia pada saat itu, sehingga dalam politik pendidikan seperti ini, telah mulai sesuai dengan tujuan politik pendidikan yang pada gilirannya politik itu adalah kebijakan yang harus disesuaikan dengan situasi atau kondisi, harus fleksibel, terbuka untuk dimodifikasi pada saat saat tertentu, kemudian politik tersebut juga harus merupakan implementasi dan aplikasi dari norma fundamentalis (pancasila) pada setiap saat dan di setiap tempat. ${ }^{8}$

${ }^{7}$ G.A. Almond \& J.S Coleman, (ed), The Politics of The Developing (Area: Princton University Press, 1960), h. 14-15.

${ }^{8}$ Moertopo, The Acceleration and Modernization of 25 Year Development (Jakarta: CSIS, 1973), h. 10.

Wacana Politik Husniah 


\section{Wacana Perkembangan Demokrasi di Indonesia terhadap Penempatan Pendidikan}

Sejak Indonesia Merdeka pada Tanggal 17 Agustus 1945, pada saat itulah awal mula lahirnya demokrasi di Indonesia. Bangsa Indonesia menyatakan dirinya dan bersepakat bahwa untuk kehidupan masyarakat, bangsa, dan negara harus diatur dengan sistem demokrasi (dari rakyat, oleh rakyat, dan untuk rakyat). Dalam perjalanan historis bangsa Indonesia, praktik demokrasi tersebut telah mengalami pasang surut atau fluktuasi. Indikasi yang riil dari fluktuasi tersebut adalah dikenalnya sistem demokrasi parlementer, demokrasi terpimpin, dan demokrasi pancasila dalam sejarah ketatanegaraan Indonesia. Masing-masing pemerintahan dengan sistem tersebut telah menginterpretasi atau mempraktekkan demokrasi secara berbeda. Karena hal-hal yang yang bersifat positif, maka muncullah hal-hal negatif yang merupakan deskripsi antara esensi demokrasi dengan pelaksanaan di lapangan.

Pada dasarnya esensi demokrasi tersebut terletak pada pemuliaan harkat dan martabat kemanusiaan manusia (human dignity). Harkat dan martabat itu merupakan karunia Allah swt. yang diberikan kepada manusia. Semua manusia telah dianugrahi Allah swt. potensi untuk beragama, kebebasan untuk berpikir, kebebasan untuk memilih, dan berbuat, persamaan kemanusiaan dan kedudukan yang lebih mulia apabila dibandingkan dengan makhluk lain. Oleh sebab itu, dalam konteks ini, apapun labelnya yang dilekatkan pada sistem demokrasi yang dikembangkan, selama sistem tetap memuliakan harkat dan martabat kemanusiaan manusia, maka ia layak disebut sebagai sistem demokrasi. Sebaliknya, jika sistem itu tidak menghormati dan tidak pula memuliakan harkat dan martabat kemanusiaan manusia, maka sistem itu pada dasarnya bukanlah sistem yang demokratis.

Fakta historis yang tidak dapat dipungkiri bahwa sejak kemerdekaan 1945, pelaksanaan demokrasi oleh beberapa generasi kepemimpinan nasional telah membawa sejumlah kemajuan dalam kehidupan kemasyarakatan dan kebangsaan, baik dalam aspek politik, ekonomi, sosial, budaya, maupun dalam keberagamaan. Namun, karena demokrasi bukanlah merupakan barang yang sudah jadi, tetapi merupakan hasil perkembangan bertahap dari sebuah proses dan alat perjuangan kekuasaan, ${ }^{9}$ maka sudah pasti ditemukan sejumlah kekurangan dan titik-titik kelemahannnya. Karena itu, sudah menjadi hal yang wajar apabila muncul kritik dari sejumlah kalangan terhadap pemerintah yang berkuasa berkaitan dengan praktik demokrasi beserta hasil-hasil yang dicapainya. Ketika pemerintah sedang memimpin merespon secara positif kritik tersebut, maka proses proses ke arah kehidupan demokratis sebenarnya masih terus berjalan. Tetapi, ketika pemerintah memberi respon sebaliknya, maka akan muncul perlawanan yang menyebabkan terjadinya krisis politik dan pemerintahaan. Ketika ini

\footnotetext{
${ }^{9}$ Chamarik. Saneh, Democracy and Development: A Culture Perspective (Bangkok: Local Development Intitute c/o Temporary Office Departement of Medical Science, 1993), h. 49.
} 
dibiarkan, maka yang terjadi kemudian adalah inflasi, bahkan mungkin mematikan demokrasi itu sendiri.

Terkait dengan keadaan di Indonesia, harus diakui bahwa pemerintahan orde baru yang terkenal dengan strategi penciptaan stabilitas keamanan untuk menunjang pembangunan ekonomi dan kesejahteraan rakyat, pada awalnya telah bergerak ke arah mengembangkan dan memajukan kehidupan demokrasi. Namun hal itu ternyata bergeser ke arah penciptaan situasi dan kondisi pemertahanan kepemimpinan, sehingga pada tahun 1977 selalu diwarnai oleh konflik-konflik internal yang menyebabkan bangsa Indonesia berada dalam badai krisis multi dimensi yang berlarut-larut. Kemudian, muncullah banyak tafsiran yang berbeda untuk memperbaiki bangsa ini. Hingga pada tahun 1998 terjadilah perubahan yang drastis yakni munculnya sistem reformasi di negara Indonesia yang dipelopori oleh Amien Rais. Munculnya gerakan reformasi ini menuntut demokrasi dalam berbagai dimensi kehidupan kemasyarakatan dan kebangsaan dengan harapan dapat menjadi lebih baik lagi.

Di satu sisi reformasi membawa sejumlah sisi positif dalam perjalannya. Namun ternyata di sisi lain, reformasi juga menimbulkan sejumlah akses negatif terhadap kehidupan masyarakat dan bangsa. Akses tersebut disebabkan kekurangsiapan masyarakat dan bangsa ini untuk hidup berdemokrasi. Akibatnya, reformasi yang baru saja dikerjakan mendatangkan kekikukan dan kegagapan dari hampir semua kalangan. Dalam wujudnya yang konkret, menurut Eep ${ }^{10}$ kekikukan dan kegagapan itu mewujud dalam euforia, lonjakan semangat yang tidak terkendali di mana-mana. Terlalu lamanya hak-hak rakyat dipasung, merupakan salah satu faktor penyebab terjadinya euforia tersebut. Kemudian, ketika kran kebebasan dibuka, ibarat limbah yang telah tertahan lama, air langsung mengalir dengan deras, dan membobol serta merusak benteng dan parit yang mengalirinya. Hal ini menyebabkan reformasi dipahami sebagai kebebasan untuk berbuat apa saja tanpa keteraturan, sehingga sebagaimana dinyatakan Davis dan Mayes, kebebasan yang tidak diseimbangkan dengan keteraturan sangat potensial mendorong ke arah tirani atau kewenangan. ${ }^{11}$

Analisis sederhananya adalah demokrasi merupakan instrumen yang lazim dikenal sebagai pembawa, penyalur, dan sekaligus pengembang nilai-nilai kultur demokrasi yang terwakili oleh partai-partai politik. Dalam konteks ini, para politisi dan pemimpin negara merupakan aktor yang memainkan peran penting dalam mendidik masyarakat agar memahami, menghayati, dan mengaplikasikan nilai-nilai dan budaya berdemokrasi dalam kehidupan nyata. Oleh sebab itu, maju mundurnya demokrasi pada suatu bangsa juga sangat bergantung pada sejauh mana political parties memberikan pendidikan demokrasi kepada masyarakatnya.

Selain dari peranan partai-partai politik, institusi yang memiliki potensi untuk memperbaiki nilai-nilai demokrasi dan memberikan pemahaman demokrasi ini kepada

\footnotetext{
${ }^{10}$ Eep Saefulloh Fatah, Zaman Kesempatan: Agenda Agenda Besar Demokratisasi Pasca Orde Baru (Bandung: Mizan 2000), h.27.

${ }^{11}$ Stan Davis \& Christopher Mayer, Future Wealth, sUnited States of America: Harvard Buisnis School Press, 2000), h. 126.

Wacana Politik. Husniah 
masyarakat adalah institusi pendidikan. Hal ini karena institusi pendidikan dapat memainkan peranannya dalam mendidik dan melatih masyarakat untuk menjadi warga negara yang aktif dan bertanggung jawab dalam mempraktikkan demokrasi. Masih dalam konteks yang sama, bahwa pendidikan merupakan sarana vital untuk menumbuhkembangkan nilai dan kultur demokrasi, karena pendidikan berhubungan dengan proses penyampaian, penanaman, pengamalan, dan pengembangan nilai-nilai. Sesuai dengan persfektif ini, pendidikan juga merupakan political institution. Melalui pendidikan akan dihasilkan warga negara yang bebas, mandiri, kritis, dan memahami prinsip-prinsip demokrasi. Melalui pendidikan, seseorang dapat dididik untuk berdisiplin, bertanggung jawab, berpikir kritis, menghargai harkat dan martabat manusia, jujur, terbuka, toleran, taat pada hukum, dialogis, apresiatif terhadap perbedaan pendapat, serta mampu mengambil keputusan terbaik untuk diri dan masyarakatnya.

Ketika institusi pendidikan berhasil menanamkan nilai-nilai demokrasi kepada peserta didiknya, maka suatu masyarakat bisa berharap kehidupan bangsanya di masa depan akan berkembang ke arah yang lebih demokratis. Sebab, peserta didik yang berasal dari berbagai institusi pendidikan itulah nantinya yang akan hidup dan mengambil peran dalam kehidupan masa depan. Akan tetapi, jika institusi pendidikan gagal dalam menanamkan nilai-nilai demokrasi, maka kehidupan masyarakat akan merosot kembali ke arah masyarakat feodalistik, autokrasi, dan otoriter.

Satu hal yang harus dianalisis adalah bahwa sebelum institusi pendidikan menanamkan dan mengembangkan nilai-nilai demokrasi kepada peserta didiknya, maka sistem dan praktik-praktik yang dikembangkan dalam institusi pendidikan haruslah merupaka sistem dan praktik yang demokratis juga. Ketiadaan sistem demokrasi pada institusi pendidikan akan memperlemah dan menyebabkan ketidakmampuan untuk menciptakan generasi yang memiliki pengetahuan, sikap, dan keterampilan dalam mengamalkan nilai-nilai demokrasi. Karena itu, pemerintah selayaknya tidak mengintervensi dan membatasi kebebasan institusi-institusi pendidikan dalam mengembangkan sistem dan praktik demokrasi.

Bila dicermati, salah satu penyebab utama kekurangmampuan dan kegagalan institusi pendidikan dalam mengajarkan dan menanamkan kultur dan nilai-nilai demokrasi kepada peserta didik atau masyarakaat secara umum adalah disebabkab adanya intervensi politik ke dalam dunia pendidikan. Menurut Bukhari, lembaga lembaga pendidikan kita mulai digerogoti oleh sistem birokrasi yang berwatak politis. Kemudian, pada tahun 1978, muncul suasana yang sangat restriktif, yang pada dasarnya mengatakan bahwa yang boleh berpikir hanya birokrasi pendidikan saja. Birokrasilah yang menentukan segala-galanya dalam kehidupan pendidikan Indonesia. Sejak saat itu, guru dan petugas pendidikan hanya berperan sebagai pelaksana dari segala sesuatu yang telah diputuskan oleh birokrasi tersebut.

Realitas di atas telah menyebabkan institusi-institusi pendidikan masih harus berupaya lagi dalam mengembangkan nilai-nilai demokrasi, seperti kesopansantunan, 
egaliter, terbuka, saling pengertian, tanggung jawab, disiplin, kesamaan, kebersamaan, keadilan, serta penghormatan terhadap harkat dan martabat hak-hak azasi manusia.

Menurut Ma'arif, realitas sejarah di Indonesia menunjukkan bahwa institusi pendidikan dijadikan sebagai sarana dalam mempertahankan kepemimpinan. Sistem pendidikan yang bersifat sentralistik dan menekankan pada uniformitas ternyata telah mematikan keberanian para peserta didik untuk mengambil inisiatif dan prakarsa, tidak berani mengajukan pendapat dan menanggung resiko, tidak siap untuk berargumentasi dan berbeda pendapat, dan tidak mampu hidup bersama dalam suasan keberagamaan. ${ }^{12}$ Mencermati hal ini, Suparmo ${ }^{13}$ bahkan menyatakan bahwa pendidikan kita masih banyak menghasilkan manusia yang ikut-ikutan emosional dalam menghadapi persoalan masyarakat, mudah berkelahi dan berperang, menjarah orang lain, dan sulit menghargai gagasan yang berbeda. Mereka belum dapat hidup berdemokrasi dengan orang lain. Karena itu, sejak bergulirnya proses reformasi justru terjadi berbagai kasus tindak kekerasan, pelanggaran terhadap hak-hak azasi manusia, dan kecenderungan kurang merasa bermasyarakat untuk hidup bersama dalam suasana kebebasan hidup yang berdemokrasi.

Berdasarkan uraian panjang di atas, maka dapat dikemukakan bahwa perjalanan politik pendidikan dalam perkembangan demokrasi di Indonesia ternyata masih membutuhkan perhatian yang lebih serius. Hal ini sesuai dengan pernyataan yang dikemukakan oleh Rocky Gerung dalam acara Indonesia Lawyer Club (ILC) pada salah satu stasiun televisi swasta. Beliau berkomentar bahwa pendidikan masih terus dipengaruhi oleh pemerintah dalam menjalankan kekuasaannya, termasuk pada kasus yang baru-baru terjadi, yang salah seorang ketua partai politik telah terlibat dalam urusan lelang jabatan di sebuah kantor wilayah kementerian agama di Surabaya. Oleh karena itu, jika dilihat dari perjalanan politik pendidikan di Indonesia ternyata masih kurang kondusif. Bahkan dapat dinyatakan bahwa demokrasi pendidikan di Indonesia yang kaitannya dengan politik pendidikan masih senantiasa tumpang-tindih dengan sistem berdemokrasi di Indonesia. Jika lembaga pendidikan diberikan kebebasan yang sesuai dengan aturan perundang-undangan, maka konseptual demokrasi pendidikan di Indonesia akan lebih positif. Akan tetapi, jika lembaga pendidikan di Indonesia masih diintervensi oleh pihak tertentu, maka keberadaan demokrasi di Indonesia masih membutuhkan proses lagi untuk menjadi lebih baik. Jika dilihat dari wacana terkait dengan politik pendidikan dalam perkembangan demokrasi di Indonesia, maka dapat ditekankan lagi bahwa pentingnya kemandirian lembaga pendidikan dalam mewujudkan cita-cita pendidikan hendaknya melalui cara-cara yang independen dan hendaknya juga terus berusaha dalam menjaga integritas lembaga pendidikan tersebut. Dengan demikian, politik pendidikan dalam perkembangan demokrasi merupakan suatu cita-cita

\footnotetext{
${ }^{12}$ Zamroni, Pendidikan untuk Demokrasi: Tantangan Menuju Civil Society, Yogyakarta: BIGRAF Publishing, 2000), h. 9.

${ }^{13}$ Suparmo. Paul, Kurikulum SMU yang Menunjang Pendidikan Demokrasi dalam Sindhunata (ed) Membuka Masa Depan Anak Anak Kita: Mencari Kurikulum Abad XXI, Yogyakarta: Kanisius, 2000), h. 79.

Wacana Politik Husniah 
yang hendaknya dipahami oleh generasi muda sebagai penerus bangsa. Suatu bangsa yang maju adalah bangsa yang peka terhadap urusan pendidikan. Pendidikan hendaknya disesuaikan dengan iklim demokrasi yang sehat agar terwujud sistem pendidikan yang lebih baik demi kemajuan bangsa.

\section{PENUTUP}

Pentingnya demokrasi dalam menempatkan pendidikan sudah sepatutnya diciptakan dalam menuju bangsa yang berkemajuan. Perhatian terhadap pendidikan hendaknya disesuaikan dengan kebutuhan masyarakat Indonesia dan terhindar dari intervensi kepentingan-kepentingan perorangan, kelompok, maupun tokoh-tokoh berpengaruh. Apabila pendidikan masih dintervensi oleh pemerintah demi kekuasaannya maka, demokrasi pendidikan tersebut tidaklah sehat. Oleh sebab itu, maka dapat disimpulkan bahwa dalam menciptakan negara yang sejahtera dan bermartabat tentunya harus berawal dari pembenahan, mulai dari penguasa dalam menggunakan kekuasaannya demi terwujudnya negara yang terhindar dari perpecahan dan perdebatan yang kurang berguna, menuju negara yang cerdas, sejahtera, dan berkemajuan.

\section{REFERENSI}

Roger. Dale, The State and Education Policy, Milton Keynes, UK: Open University Press, 1989.

Kimbrough, Political Powerand Educational Decision-Making, Chicago: Rand Mcnally \& Company, 1964

Marbun. BN, Kamus Politik, t.k, 2002.

Shadily. John M.Echols. Kamus Inggris Indonesia, Cet.VIII, Jakarta: Gramedia, 1990.

Sirozi. Muhammad, Politik Kebijakan Pendidikan di Indonesia Peran Tokoh-tokoh Islam dalam Penyususnan UU No.2 Tahun 1989, Jakarta: INIS, 2004.

Almond, G.A \& Coleman, J.S (ed) The Politics of The Developing Area. Princton University Press, 1960.

Moertopo, The Acceleration and Modernization of 25 Year Development, Jakarta: CSIS, 1973.

Chamarik. Saneh, Democracy and Development: A Culture Perspective, Bangkok: Local Development Intitute c/o Temporary Office Departement of Medical Science, 1993.

Fatah. Eep Saefulloh, Zaman Kesempatan: Agenda Agenda Besar Demokratisasi Pasca Orde Baru, Bandung: Mizan 2000. 
Davis. Stan \& Christopher Mayer, Future Wealth, sUnited States of America: Harvard Buisnis School Press, 2000.

Zamroni, Pendidikan untuk Demokrasi: Tantangan Menuju Civil Society, Yogyakarta: BIGRAF Publishing, 2000.

Suparmo. Paul, Kurikulum SMU yang Menunjang Pendidikan Demokrasi dalam Sindhunata (ed) Membuka Masa Depan Anak Anak Kita: Mencari Kurikulum Abad XXI, Yogyakarta: Kanisius, 2000. 